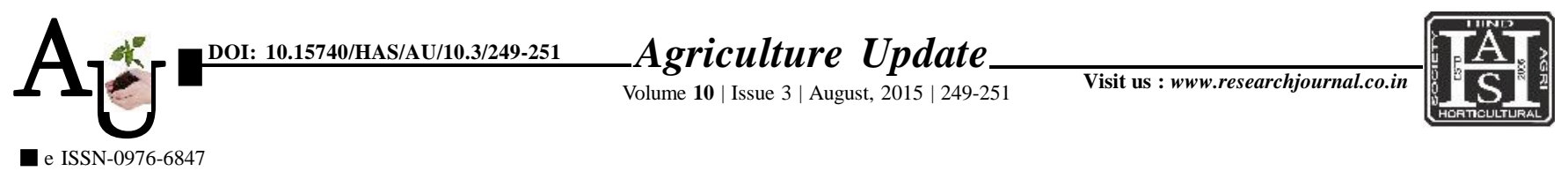

\title{
Research Article: Extent of adoption of recommended paddy production technology
}

H.N. MAHERIYA, J.K. PATEL AND R.C. PATEL

Article Chronicle: Received :

08.06.2015;

Revised :

21.07.2015;

Accepted :

18.08.2015

KEY WoRds:

Extent of adoption, Paddy production technology

Author for correspondence :

\section{H.N. MAHERIYA}

Department of Extension Education, B.A. College of Agriculture, Anand Agricultural University, ANAND (GUJARAT) INDIA Email: hiten2889@ gmail.com

See end of the article for authors' affiliations
SUMMARY : The "adoption process" is the mental process through which an individual passes from first hearing of an innovation to its final adoption, while adoption is a decision to continue the full use of an innovation. Generally, the farmers do not adopt package of practices fully. There is only a partial adoption by them. As a result, the gap always appears between the recommended production technology and their use at farmer's field. Considering the facts, an attempt was made to find out the extent of adoption of recommended paddy production technology by the farmers. To collect the information pertaining to the study 120 respondents were selected by proportionately from 10 randomly selected villages of Khambhat and Tarapur taluka of Anand district.

How to cite this article : Maheriya, H.N., Patel, J.K. and Patel, R.C. (2015). Extent of adoption of recommended paddy production technology. Agric. Update, 10(3): 249-251. 